$\begin{array}{cc}\text { Türkiye Tarımsal Araştırmalar Dergisi } & \text { Turk J Agric Res } \\ \text { http://dergi.siirt.edu.tr } & \text { (2016) 3: 23-29 } \\ \text { OC TÜTAD } & \text { ISSN: 2148-2306 } \\ \text { Adoi: 10.19159/tutad.89499 }\end{array}$

\title{
Güneydoğu Anadolu Bölgesi’nde Zeytin Ağaçlarında Zarar Yapan Zeytin Güvesi, Prays oleae (Bern.) (Lepidoptera: Hyponomeutidae)'nin Yayılışı, Popülasyon Değişimi ve Bulaşma Oranı Üzerine Çalışmalar
}

\author{
Cevdet KAPLAN ${ }^{1 *}$, Musa BÜYÜK ${ }^{2}$, Sedat EREN ${ }^{3}$ \\ ${ }^{I}$ Siirt Üniversitesi, Ziraat Fakültesi, Bitki Koruma Bölümü, Siirt, TÜRKIYYE \\ ${ }^{2}$ Dicle Üniversitesi, Diyarbakır Tarım Meslek Yüksekokulu, Diyarbakır, TÜRKIYYE \\ ${ }^{3}$ Zirai Mücadele Araştırma Enstitüsü, Diyarbakır, TÜRKIYE
}

\begin{abstract}
Geliș Tarihi/Received: 16.10 .2015
Kabul Tarihi/Accepted: 15.12 .2015

"Sorumlu yazar/Corresponding author: cevdetkaplan@hotmail.com

Özet: Bu çalışma Mardin, Gaziantep ve Şanlıurfa illerinde Zeytin güvesi, Prays oleae (Bern.)'nin popülasyon değişimi ve bulaşma oranını belirlemek amacıyla 2001-2002 yıllarında yürütülmüştür. Bahçelere Nisan ayı başlarında cinsel çekici tuzaklar asılmıștır. Tuzaklar başlangıçta haftada iki, ilk kelebek yakalandıktan sonra ise haftada bir kez kontrol edilmiștir Kontrollerde tuzaklara gelen kelebekler sayılarak kaydedilmiştir. Tuzaklarda yakalanan erginlerin yıllar ve bahçelere göre popülasyon eğrileri çizilmiştir. Zarar oranı belirlemesi için yılda üç kez örnekleme yapılmıştır. Yaprak ve çiçek zararının tespiti için her bahçede 10 ağaç ve her ağacın farklı dört yönünde $15-20 \mathrm{~cm}$ uzunluğundaki sürgünler, meyve zararı için ise her bahçede 10 ağaç ve her ağacın farklı yönlerinde 5 meyve (her ağaçta 20 meyve) kontrol edilmiştir. Ergin uçuşunun Nisan ayının ikinci haftasında başladığı; 1. ve 2. döl erginlerinin birbirine karışarak ergin uçuşunun Haziran ayı ortasına kadar devam ettiği görülmüştür. Üçüncü döl ergin çıkışlarının Eylül ayının ikinci haftasında başlayıp Kasım ayı ortalarına kadar devam ettiği ve zararlının 3 döl verdiği belirlenmiștir. Zarar oranı bahçelere ve illere göre değişmekle beraber yaprakta \% 3-5, çiçekte \% 0.3-3 ve meyvede \% 0.5-3 olarak belirlenmiştir. Yapılan çalışma ile P. oleae'nın GAP bölgesinde potansiyel zararlı olduğu belirlenmiştir.
\end{abstract}

Anahtar Kelimeler: Prays oleae, yayılış, popülasyon dalgalanması, bulaşma oranı

\section{Studies on the Distribution, Population Fluctuation and Infestation Level of Olive Moth, Prays oleae (Bern.) (Lepidoptera: Hyponomeutidae) Causing Damage on Olive Trees in Southeast Anatolian Region, Turkey}

\begin{abstract}
This study were carried out to determine the distribution, population fluctuation and infested level of Olive moth Prays oleae (Bern.) in Mardin, Gaziantep and Şanlıurfa provinces during 2001-2002. The pheromone traps were hanged on the trees in orchards at the beginning of April. The traps were checked twice a week until the first moth was caught, then they were checked weekly up to the end of season. The level of damage was determined by examining leaves, blossoms and fruit. Sampling was conducted 3 times in a year. The shoots $15-20 \mathrm{~cm}$ in length were taken from 4 directions of the trees in each orchard to estimate the damage caused by phyllophagous and anthophagous generation. Five olive fruit from each direction (total 20 from each tree) of the tree were sampled to determine the damage on fruit from 10 trees in each orchard for the carpophagous generation. As a result, it is found that adult moth activity begins in early April. Adults of first and second generation were seen together until mid-June. Activity of third generation adult started at the beginning of September until mid-November. The population curves were plotted based on weekly catches. The pest passes 3 generation a year. Damage level was different in each orchard and year. Damage level estimated, in general caused by phyllophagous, anthophagous and carpophagous were 3-5\%, 0.3-3\%, 0.5-3\% respectively. Although adult moths that caught on trap were high, the damage level was very low. In conclusion this pest could be potencial pest in GAP region for now.
\end{abstract}

Keywords: Prays oleae, distribution, population fluctuation, infestation level 


\section{Giriş}

Zeytin, Türkiye'deki tarımsal ürünler içerisinde ve ülke ekonomisinde önemli bir yere sahiptir. Sofralık ve yağlık olarak kullanılması nedeniyle son y1llarda özellikle insan beslenmesinde temel gıda maddelerinden biri haline gelmiştir. Zeytin, yağı ve sofralık zeytin olarak ihraç edilmesi ve artıklarının yan sanayi için iyi bir hammadde olması ekonomik olarak önemi her geçen gün artmaktadir.

Türkiye'de zeytin alanları, 2000 yılından sonra devlet tarafindan verilen sertifikalı fidan ve bahçe tesisi desteği sayesinde artarak işlenen toplam tarım alanlarının \% 3.4'üne ulaşmıştır (Tunalığlu, 2015).

Ülkemizde yaklaşık 825 bin hektar alanda, 169 milyon ağaç varlığı ile 1.768 .000 ton zeytin üretimi yapılmaktadır. Güneydoğu Anadolu Bölgesi Türkiye zeytin ağaç varlığının $\%$ 9.09'unu, üretimin ise \% 3.70'ine sahiptir (Anonim, 2014). Zeytin, ihraç edilen tarımsal ürünler içerisinde önemli bir yere sahiptir. Türkiye'de üretilen zeytin yağının yaklaşık $\%$ 50'si, sofralık zeytinin ise \% 25'i ihraç edilmektedir (Özkaya ve ark., 2010).

Zeytinin kalite ve verimini etkileyen önemli faktörlerden birisi de hastalı ve zararlı böceklerdir. Özellikle direk meyvede zarar yapan zararlı böcek türleri kalite üzerinde etkilidirler. Zeytin kalitesine etki eden en önemli zararlılar Zeytin sineği (Bactrocera oleae Gmelin), Zeytin güvesi (Prays oleae Bern.), Zeytin karakoşnili (Saissetia oleae Olivier) ve Zeytin kabuklubiti (Parlatoria olea Colv.)'dir. Bu zararlılar özellikle sofralık zeytinde önemli kalite kaybına neden olmaktadir.

Zeytin güvesi yaprak, çiçek ve meyvede zarar yaparak doğrudan ve dolaylı olarak ürün kayıplarına ve ürün kalitesinin bozulmasına neden olmaktadır.

Ülkemizde Zeytin güvesi ile ilgili olarak farklı bölgelerde günümüze kadar bazı çalışmalar yapılmıştır. Zeytin üretiminde önemli ekonomik kayıplara neden olan ana zararlılardan birisi olarak kabul edilen Zeytin güvesinin Çakıllar (1959), Marmara Bölgesi'nde biyolojisi; Bozan ve ark. (1994), Karadeniz Bölgesi'nde popülasyon değişimi ve zarar oranı; Güçlü ve ark. (1995), Artvin ilinde bulaşıklık durumu; Yayla (1983), Antalya ilinde bulaşıklık durumu ve doğal düşmanları; Başpınar ve ark. (1996), Aydın ilinde bulaşıklık oranı; Kaplan ve ark. (2004), Güneydoğu Anadolu Bölgesi'nde popülasyon değişimi ve bulaşma oranı; Çetin ve Alaoğlu (2005), Mut (Mersin) ilçesinde popülasyon değişimi ve zararı üzerinde araştırmalar yapmışlardır. Yurtdışında Zeytin güvesi kimyasal mücadelesine alternatif olabilecek çevre dostu mücadele çalışmaları yapılmıştır. Hegazi ve ark. (2009), Mısır'da Zeytin güvesine karşı çiftleşmeyi engelleme (şaşırtma tekniği) yönteminin etkinliğini araştırmışlardır.

Zeytin güvesi yaprak ve sürgünlerde, çiçek ve çiçek tomurcuklarında ve meyvelerde zarar meydana getirmek suretiyle yılda 3 döl vermektedir. Ramos (1998), bu zararlı tür tarafından oluşturulan zararı üç kategoriye ayırmış ve son dölün meyvede \% 40'a varan yüksek oranda meyve dökümüne neden olduğunu bildirmektedir. Bu nedenle zararlı ile mücadeleye karar vermek için her döle ait ergin uçuş dönemi ve zarar oranının saptanması önem taşımaktadır. $\mathrm{Bu}$ çalışmanın amacı, son yıllarda Güneydoğu Anadolu Bölgesi'nde dikim alanları giderek artan zeytinde bazı üreticilerden gelen meyve dökümü şikâyetti üzerine zeytin alanlarında bulunan Zeytin güvesinin yayılışı, popülasyon değişimi ve bulaşma oranını belirlemek olmuştur.

\section{Materyal ve Yöntem}

Çalışmanın ana materyalini Adıyaman, Gaziantep, Mardin ve Şanlıurfa illerindeki zeytin ağaçları ve bunlarda zarar oluşturan Zeytin güvesi oluşturmuştur. Örnekleme malzemeleri olarak; feromonlar, eşeysel çekici tuzaklar vb. diğer materyaller kullanılmıştır.

Güneydoğu Anadolu Bölgesi zeytin alanlarında zararlı olan Zeytin güvesinin yayılış alanını belirlemek için zeytin yetiştiriciliğinin yapıldığ bölge illerinin (Adiyaman, Gaziantep, Mardin ve Şanlıurfa) ikişer ilçesinde, her ilçenin ayrı yönlerinde olmak üzere iki yöresinde, o yöreyi karakterize edecek şekilde seçilen ikişer bahçede, tüm vejetasyon süresince 2-4 haftalık arayla toplam 52 bahçede inceleme yapılmıştır.

Zeytin güvesinin ergin uçuş seyri ve popülasyon yoğunluğu 2001-2002 y1lları arasında zeytin yetiştiriciliğinin en fazla yapıldığg farklı ekolojilere sahip Gaziantep ilinin Nizip ilçesinde bir bahçede, Mardin ilinin Derik ilçesinde ise iki farklı yöredeki 2 bahçede izlenmiştir.

Ergin uçuş seyri ve popülasyon yoğunluğunun takibi için çalışmanın yapıldığı her bahçeye, ağaçların güneydoğu cephesine gelecek şekilde 1.5 $\mathrm{m}$ yüksekliğe bir adet delta tipi eşeysel tuzak asılmıştır. Sayımlar kış aylarında ayda bir ya da iki kez, diğer aylarda haftada bir veya iki haftada bir kez yapılmıştır. Tuzaklar içindeki eşeysel feromon kapsülleri ayda bir, yapışkan tabla ise kirlendikçe değiştirilmiştir. 
Zararlının bulaşma oranının belirlemesi için ise Mardin, Gaziantep ve Şanlıurfa illerinin ikişer ilçesinde ve her ilçede iki bahçede yılda üç kez örnekleme yapılmıştır. Yaprak ve çiçek zararının tespiti için her bahçede 10 ağaç ve her ağacın dört farklı yönünde 15-20 cm uzunluğundaki sürgünler, meyve zararı için ise her bahçede 10 ağaç ve her ağacın farklı yönlerinde 5 meyve (her ağaçta 20 meyve) laboratuvara getirilmiş ve zarar görenler sayılarak bulaşıklık oranları saptanmıştır (Başpınar ve ark., 1996).

\section{Bulgular ve Tartışma}

\subsection{Yayılış}

Prays oleae'nın Güneydoğu Anadolu Bölgesi'nde zeytin üretim alanlarındaki yayılışını belirlemek için Adıyaman, Gaziantep, Mardin ve Şanlıurfa illerinde kontrol edilen toplam 52 bahçenin \% 80.76'sında bu zararlıya rastlanılmıştır (Tablo 1). En fazla Mardin (Derik) ilinde, en az ise Adıyaman ilinde yaygın olduğu görülmüştür. Zeytin güvesi, ülkemizde zeytin yetiştirilen her yerde bulunduğu belirtilmektedir (Anonim, 2008).

\subsection{Ergin uçuş seyri ve popülasyon yoğunluğu}

Prays oleae'nın ergin uçuşu bahçeler ve yıllar bazında değerlendirildiğinde; Mardin (Derik) ili Kale mevkiindeki bahçede 2001 yılında birinci döl ergini 10 Nisan'da yakalanmıştır. Zararlının yıl içerisinde üç tepe noktası oluşturduğu, birinci dölde 24 Nisan'da, ikinci dölde 05 Haziran'da ve üçüncü dölde ise 11 Ekim tarihinde en yüksek sayıya ulaşmıştır. Birinci döl ve ikinci döl erginlerinin birbirine karıştı̆̆ 1 , ikinci döl erginlerinin 21 Haziran tarihine kadar doğada bulunduğu görülmüştür. Üçüncü döl ergin uçuşunun 07 Eylül'de başladığı ve 25 Ekim tarihine kadar devam ettiği belirlenmiştir. Aynı bahçede 2002 yılında ise birinci dölün erginleri 16 Nisan tarihinde tuzaklarda tespit edilmiştir. Birinci ve ikinci dölün erginlerinin birbirine karıştığ görülmüş, birinci dölde 02 Mayıs tarihinde 370 adet ergin/tuzak ve ikinci dölde ise 17 Haziran'da 346 adet ergin/tuzak ile en fazla ergin yakalanmıştır. İkinci döl ergin uçuşunun 11 Temmuz tarihine kadar devam ettiği saptanmıştır. Üçüncü dölün erginleri tuzakta 09 Eylül tarihinde belirlenmiş ve ergin uçuşunun 06 Kasım'a kadar

Tablo 1. Prays oleae (Bern.)'nin 2001-2002 yıllarında Güneydoğu Anadolu Bölgesi'nde saptandığı il, ilçeler ve bulaşık bahçe oranları

\begin{tabular}{llccr}
\hline İl & İlçe & $\begin{array}{c}\text { Kontrol edilen bahçe } \\
\text { sayıs1 (adet) }\end{array}$ & $\begin{array}{c}\text { Bulaşık bahçe sayıs1 } \\
\text { (adet) }\end{array}$ & $\begin{array}{c}\text { Bulaşık bahçe oran1 } \\
(\%)\end{array}$ \\
\hline Adıyaman & Besni & 4 & 3 & 75.00 \\
& Merkez & 2 & 0 & 0.00 \\
\hline Gaziantep & Nizip & 10 & 8 & 80.00 \\
& Merkez & 6 & 6 & 100.00 \\
\hline Mardin & Derik & 12 & 12 & 100.00 \\
& Merkez (Dara) & 4 & 3 & 75.00 \\
\hline Şanliurfa & Ceylanpınar & 6 & 4 & 66.66 \\
& Bilecik & 8 & 6 & 75.00 \\
\hline Toplam & & 52 & 42 & 80.76 \\
\hline
\end{tabular}

devam ettiği ve en yüksek sayıya (320 adet ergin/tuzak) 21 Ekim tarihinde ulaştığ saptanmıştır (Şekil 1).

Mardin (Derik) GAP mevkiindeki P. oleae'nin 2001 yılında birinci döl erginleri 10 Nisan tarihinde tuzaklarda yakalanmıştır. En fazla ergin çıkışı birinci dölde 23 Nisan'da, ikinci dölde 05 Haziran'da ve üçüncü dölde ise 11 Ekim tarihinde belirlenmiștir. İkinci döl ergin uçuşu 21 Haziran tarihine kadar devam etmiştir. Üçüncü döl ergin çıkışları 16 Eylül'de başlamış ve Ekim ayının sonuna kadar devam etmiştir. Aynı bahçede 2002 y1lında ise $P$. oleae'nin birinci döl erginleri 19 Nisan'da belirlenmiştir. Birinci ve ikinci döl ergin uçuşlarının karıştığı görülmüştür. İkinci dölde en fazla ergin çıkışı (448 adet ergin/tuzak) 12 Haziran'da olduğu saptanmıştır. Üçüncü döl erginlerine tuzakta 18 Eylül'de rastlanılmış ve ergin uçuşu 26 Kasım tarihine kadar devam etmiştir. Üçüncü dölde en fazla ergin çıkışının 26 Ekim'de olduğu belirlenmiştir (Şekil 1).

Gaziantep (Nizip)'deki bahçede 2001 y1lında $P$. oleae'nin ilk erginlerine tuzakta 12 Nisan'da rastlanmıştır. Birinci dölde en fazla ergin çıkışı 25 Nisan'da, ikinci dölde ise 08 Haziran'da belirlenmiştir. İkinci döl erginlerinin 09 Temmuz tarihine kadar doğada görüldüğü saptanmıştır. Tuzaklarda üçüncü döl erginleri 18 Eylül'de tespit edilmiştir. Ergin uçuşunun 13 Kasım'a kadar devam ettiği ve en fazla (320 adet ergin/tuzak) ergin çıkışının 11-26 Ekim arasındaki dönemde olduğu saptanmıştır. $\mathrm{Bu}$ bahçede $P$. oleae erginlerine 13 Kasım'a kadar rastlanılmıştır (Şekil 2). 


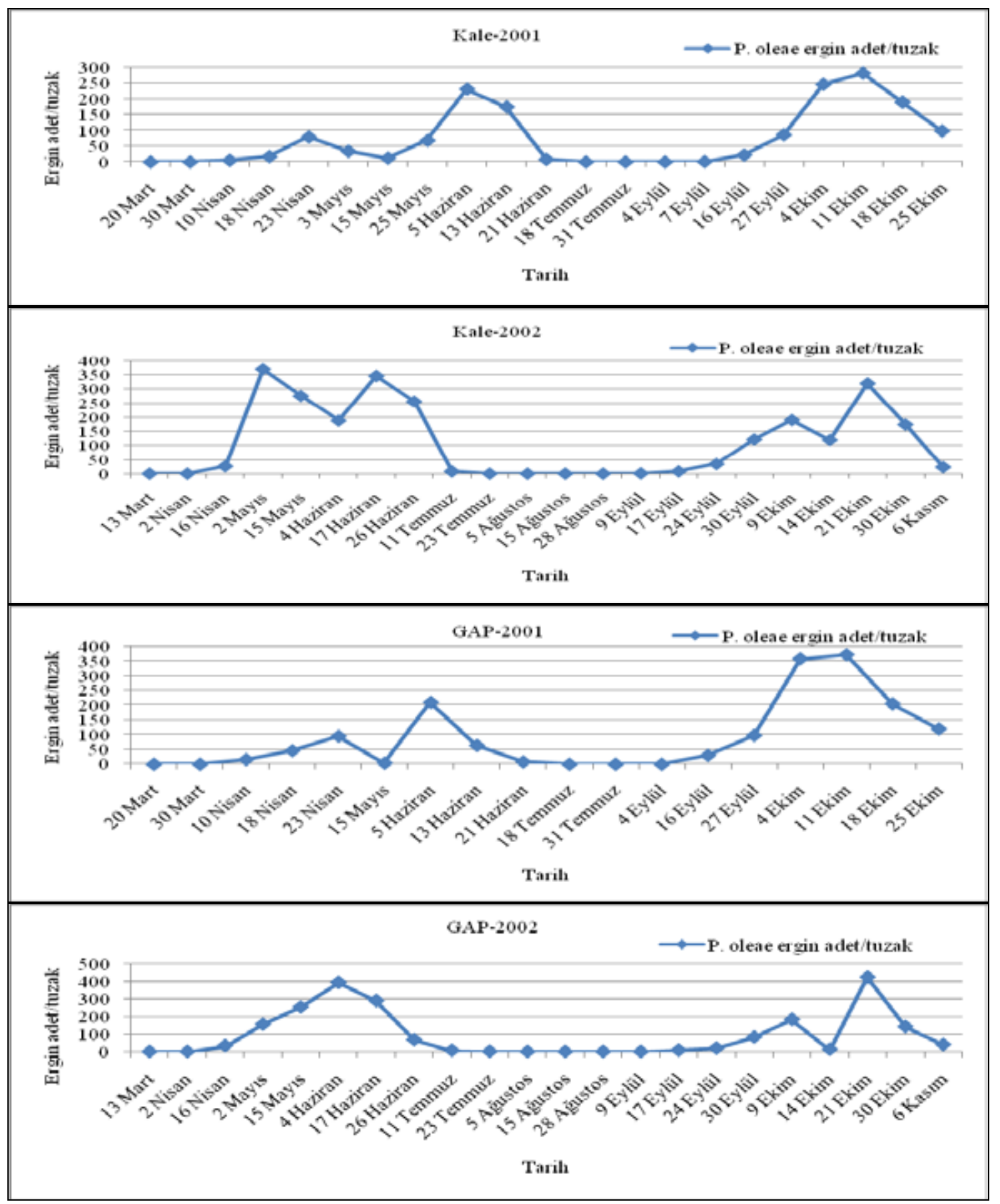

Şekil 1. Mardin'in Derik (Kale ve GAP mevkii) ilçesinde 2001-2002 yıllarında Prays oleae (Bern.)'nın uçuş seyri ve ergin yoğunluğu (ergin adet/tuzak)

Güneydoğu Anadolu Bölgesi'ndeki farklı ekolojideki üç bahçede yapılan iki yıllık çalışma sonucunda; $P$. oleae'nın birinci döl erginlerinin Nisan ayının ikinci haftası içerisinde çıkmaya başladığı, birinci ve ikinci döl erginlerinin birbirine karıştığı, ikinci döl erginlerinin Temmuz ayının ortasına kadar görüldüğü belirlenmiştir. Üçüncü döl ergin çıkışlarının Eylül ayının birinci haftasından itibaren olduğu ve Kasım ortalarına kadar devam ettiği saptanmıştır. Zararlının yıl içerisinde üç tepe noktası oluşturduğu en fazla ergin çıkışının birinci dölde Nisan sonu ve Mayıs başlarında, ikinci dölde Haziran ortasında ve üçüncü dölde ise Ekim ortasında olduğu belirlenmiştir. 2002 yılında tuzaklarda yakalanan toplam ergin sayıs1 2001 yılında yakalanan ergin sayısından fazla olmuştur.

Araştırmada, Prays oleae'nin ergin uçuş dönemleri ile ilgili bulgular daha önce yapılan 


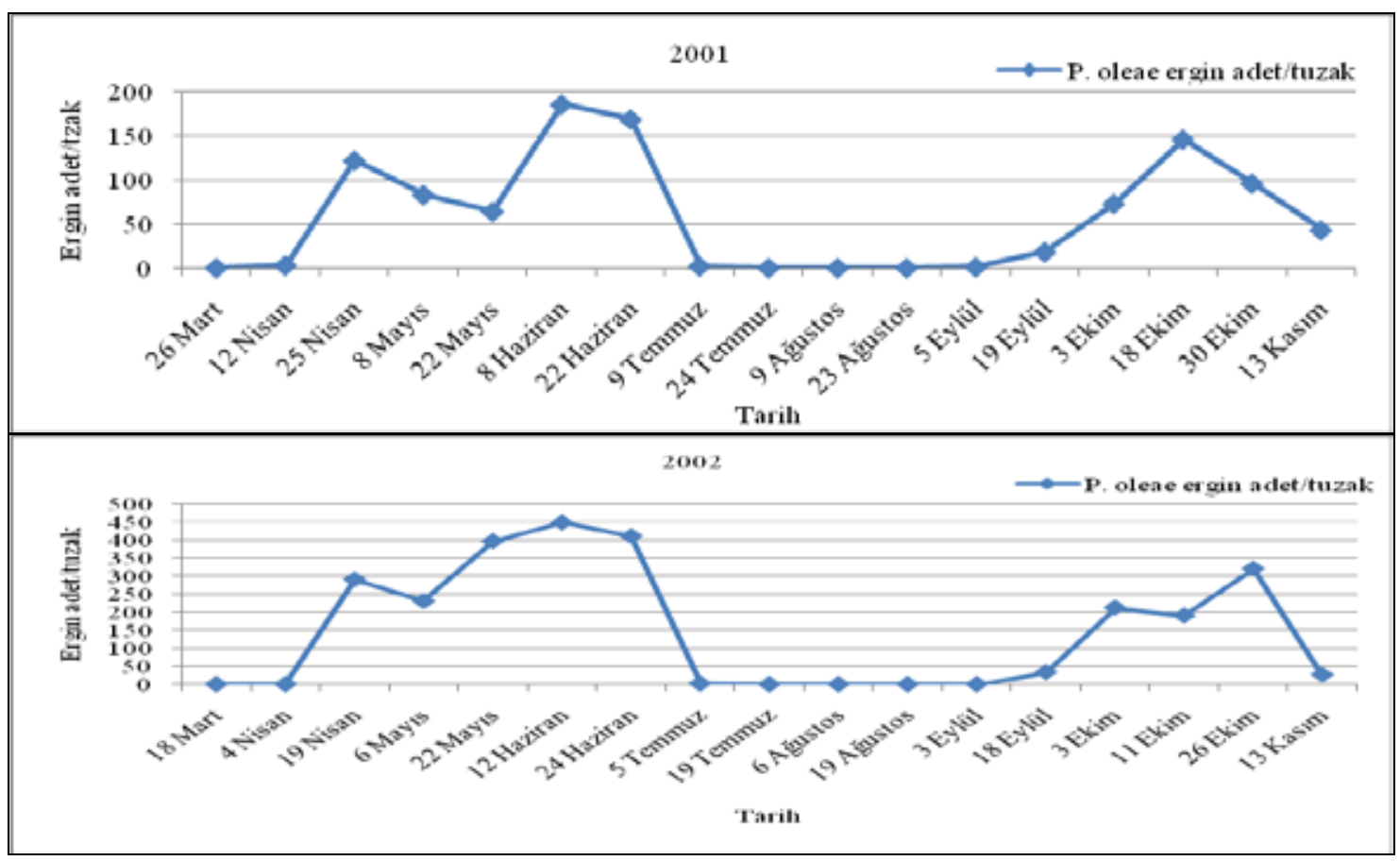

Şekil 2. Gaziantep-Nizip ilçesinde 2001-2002 yıllarında Prays oleae (Bern.)'nin uçuş seyri ve ergin yoğunluğu (ergin adet/tuzak)

çalışmalarla da desteklemektedir. Nitekim, Kaya ve ark. (1985), Ege Bölgesi'nde Zeytin güvesi çiçek nesli erginlerinin Nisan ayının ikinci on günlük periyodu içinde çıkmaya başladıklarını, 1020 Mayıs'ta tepe noktasına ulaştığını, meyve nesli erginlerinin 26 Mayıs-04 Haziran tarihleri arasında çıkmaya başladıklarını, çıkışların 10-20 Haziran tarihleri arasında en yüksek düzeye ulaştığını ve yaprak neslini meydana getirecek meyve nesli erginlerinin ise Eylül ayı ortalarından itibaren çıktıklarını belirtmektedirler.

Çakıllar (1959), Marmara Bölgesi’nde yaptığı çalışmada $P$. oleae'nın birinci döl erginlerinin Mart sonunda, ikinci döl erginlerinin Haziran ortası-Temmuz başı, üçüncü döl erginlerinin ise Eylül-Ekim başlarında çıkış yaptığını; Broumas (1987), Yunanistan'da ilk ergin uçuşunun 15 Nisan ile Mayıs sonu arasında olduğunu ve 47-51 gün sürdüğünü, ikinci döl ergin uçuşunun 21 Mayıs-08 Haziran arasında olduğunu ve hatta Temmuz başına kadar devam ettiğini; Bozan ve ark. (1994), Sinop'ta $P$. oleae ilk ergin uçuşunun Nisan sonuMayıs başında başladığını; Çetin ve Alaoğlu (2005), Mersin (Mut)'de ilk döl erginlerini 07 Nisan'da, ikinci döl erginlerini 19 Mayıs'ta, üçüncü döl erginlerini ise 14 Eylül'de saptadıklarını; Turanlı ve ark. (2011), İzmir ve Manisa'da Zeytin güvesinin yıl içerisinde 3 tepe noktası oluşturduğunu, tepe noktalarının Mayıs ortasında, Haziran'ın ikinci haftasında ve Ekim ayının ortasında oluşturduğunu, erginlerinin Nisan ayından Aralık ayına kadar doğada görüldüğünü belirtmişlerdir.

İki yıllık çalışma sonucunda y1l boyunca eşeysel çekici tuzaklarda yakalanan $P$. oleae ergin sayıları bahçeler bazında incelendiğinde; 2001 yılında en fazla 1626 adet ile Derik (GAP) mevkiindeki bahçede, 2002 yılında ise 2557 adet ile en fazla ergin yoğunluğunun Nizip ilçesindeki bahçede olduğu görülmüştür. Çalışmaların yürütüldüğü üç bahçedeki yoğunluk yıllar itibariyle değerlendirildiğinde; 2001 yılında üç bahçede 4180 adet ergin yakalanmasına rağmen, 2002 yılında ise 7138 adet ergin yakalanmıştır (Tablo 2). Ergin yoğunluğu bakımından bahçeler ve yıllar arasında farklılıklar olduğu saptanmıştır. Ergin sayısındaki farklılığa çevre faktörleri ve doğal düşmanların etkili olduğu düşünülmektedir. Ancak bu konularda herhangi bir gözlem yapılamamıştır.

Tablo 2. Mardin ve Gaziantep illerinde 2001-2002 yıllarında yıl boyunca eşeysel çekici tuzaklarda yakalanan toplam Prays oleae (Bern.) ergin sayısı (adet)

\begin{tabular}{llrl}
\hline İl & \multirow{2}{\text{İlçe}}{} & \multicolumn{2}{c}{ Ylllar } \\
\cline { 3 - 4 } & & 2001 & 2002 \\
\hline Mardin & Derik (GAP mevki) & 1.626 & 2.119 \\
& Derik (Kale mevki) & 1.548 & 2.462 \\
\hline Gaziantep & Nizip & 1.006 & 2.557 \\
\hline Toplam & & 4.180 & 7.138 \\
\hline
\end{tabular}


Katsoyannos (1992); Sacantanis (1955) ve Arambourg (1964)'a atfen bildirdiğine göre; Prays oleae yumurtaları ve yeni çıkış yapmış larvaların düşük nem ve yüksek sicaklıktan fazla etkilendikleri, orantılı nemin \% 60'ın altına inmesi durumunda yumurtaların bir kaç saat içinde kuruduğu ve $30{ }^{\circ} \mathrm{C}$ 'nin üzerindeki sıcaklıklarda yeni çıkış yapan larvaların öldükleri belirtilmektedir.

\subsection{Bulaşma oranı}

Güneydoğu Anadolu Bölgesi'nde 2001-2002 yıllarında, çalışmaların sürdürüldüğü zeytin bahçelerindeki sayım sonuçları incelendiğinde; $P$. oleae'nin GAP bölgesindeki zeytinliklerde yaprak, çiçek ve meyve dölünde \% 10 olan ekonomik zarar eşiğini aşmadığı belirlenmiştir.

Çalışma sonucunda $P$. oleae'nin bulaşma oranının yıllara ve bahçelere göre değiştiği tespit edilmiştir. Yaprakta zarar \% 3.00-5.00, çiçekte $\%$ 0.30-3.00 ve meyvede \% 0.50-3.00 arasinda değiştiği gözlenmiştir (Tablo 3). Güneydoğu Anadolu Bölgesi'ndeki zeytin bahçelerinde Zeytin güvesi görülmekte, ancak var olan doğal denge ve iklim koşulları nedeniyle şu anda pek sorun oluşturmadığı ve ilaçlamayı gerektirecek bir zarara neden olmadığı belirlenmiştir.
Başpınar ve ark. (1996), Aydın ilinde 19861993 yıllarında yaptıkları çalışmada, Zeytin güvesinin yaprak ve çiçek zararının pek önemli olmadığını ya ekonomik zarar eşiğine yaklaştığı ya da altında kaldığı, ancak meyve dölünün önemli olduğunu; Çetin ve Alaoğlu (2005), Mersin'de $P$. oleae'nin yapraktaki zararını \% $\quad 17.3-18.0$, çiçekteki zararını \% 0.7-3.3, meyvedeki zararını çalışmanın ilk yılında \% 1.3 gibi çok düşük belirlerken, ikinci yılda bahçelere göre değişmekle beraber sirasiyla $\% \quad 2, \quad \% \quad 24$ ve $\% \quad 60$ bildirmektedirler.

Elde edilen sonuçlar, $P$. oleae'nin yaprak, çiçek ve meyvedeki zararının yıl ve yerlere göre değişebildiğini göstermektedir. Zararlının meyvedeki zararının düşük olmasında, bölge illerinde zararlıya karşı kimyasal ilaçlamanın yapılmaması ile doğal dengenin bozulmamış olması ve yaz aylarındaki yüksek sıcaklık gibi iklim faktörlerinin etkili olduğu tahmin edilmektedir. Nitekim Afellah ve ark. (1998), Fas'ta yaptığı çalışmada; Prays oleae'da parazitlemenin \% 0.12-0.36 ve iklim koșullarından dolayı yumurta ölümünün \% $0-43.46$ olduğunu, predatör türlerden Chrysoperla carnea'nın zararlının yoğunluğunu \% $\quad 4.8-35.7$ oranında azalttığını belirlemişlerdir.

Tablo 3. Prays oleae (Bern.)'nin 2001-2002 yıllarında Güneydoğu Anadolu Bölgesi zeytin alanlarında yaprak, çiçek ve meyve döllerinin oluşturduğu bulaşıklık oranları (\%)

\begin{tabular}{|c|c|c|c|c|c|}
\hline \multirow[t]{2}{*}{ İller } & \multirow[t]{2}{*}{ İlçeler } & \multirow[t]{2}{*}{ Y11 } & \multicolumn{3}{|c|}{ Ortalama bulaşıklık } \\
\hline & & & Yaprak & Çiçek & Meyve \\
\hline \multirow{4}{*}{ Mardin } & Derik & 2001 & 4.33 & 2.30 & 2.20 \\
\hline & (GAP mevki) & 2002 & 5.00 & 3.00 & 2.80 \\
\hline & Derik & 2001 & 3.50 & 2.80 & 2.50 \\
\hline & (Kale mevki) & 2002 & 4.86 & 2.60 & 3.00 \\
\hline \multirow{4}{*}{ Gaziantep } & \multirow{2}{*}{ Nizip } & 2001 & 3.25 & 0.75 & 1.00 \\
\hline & & 2002 & 3.44 & 2.50 & 2.00 \\
\hline & \multirow{2}{*}{ Merkez } & 2001 & 3.00 & 1.25 & 1.50 \\
\hline & & 2002 & 4.10 & 2.75 & 1.00 \\
\hline \multirow{4}{*}{ Şanlıurfa } & \multirow{2}{*}{ Birecik } & 2001 & 3.55 & 2.00 & 2.00 \\
\hline & & 2002 & 4.00 & 3.00 & 3.00 \\
\hline & \multirow{2}{*}{ Ceylanpınar } & 2001 & 3.10 & 0.30 & 0.50 \\
\hline & & 2002 & 3.00 & 2.00 & 2.00 \\
\hline
\end{tabular}

\section{Sonuçlar}

P. oleae'nın şu anda Güneydoğu Anadolu Bölgesi'nde zeytin bahçelerinde potansiyel zararlı durumunda olduğu saptanmıştır. Artan zeytin alanlarında mevcut doğal dengenin korunması, olası gereksiz ilaçlamaların önüne geçilmesi için üretici eğitimlerine öncellik verilmesi gerekmektedir. Zeytin alanlarında Zeytin güvesi ve diğer zararlılara karşı yapılacak uygulamalarda çevre dostu uygulamalara öncellik verilmesi, kimyasal mücadelenin gerektiği durumlarda ise hedef zararlıya spesifik ilaçların kullanılmasına öncellik verilmelidir.

\section{Teşekkür}

Bu çalışma, TARP-2516 No'lu TÜBİTAK tarafından desteklenen projenin bir bölümünden üretilmiştir. 


\section{Kaynaklar}

Affellah, M., Smaili, C., El-Hajouii, A., 1998. Factors influencing mortality and predation of eggs of Prays oleae Bern. (Lep., Hyponom.) in the Sais region of Morocco. Mededelingen- Faculteit Landbouwkundige en Toegepaste Biologische Wetenschappen, 63(2a): 345-355.

Anonim, 2008. Zirai Mücadele Teknik Talimatları, Cilt 5. T.C. Tarım ve Köyişleri Bakanlığı, Tarımsal Araştırmalar Genel Müdürlüğü, Ankara.

Anonim, 2014. Türkiye İstatistik Kurumu (TÜİK) Bitkisel Üretim İstatistikleri. http://www.tuik.gov.tr (Erişim tarihi: 22.11.2014).

Başpınar, H., Güngör, H., Öncüer, C., 1996. Zeytin güvesi, Prays oleae (Bern.) (Lepidoptera, Hyponomeutidae)'nin Aydın ili zeytin alanlarındaki bulaşıklık oranı üzerinde çalışmalar. Türkiye 3 . Entomoloji Kongresi, 24-28 Eylül, Ankara, s. 85-89.

Bozan, İ., Yıldırım, A.F., Kılıç, M., 1994. Karadeniz Bölgesi zeytin ağaçlarında zarar yapan zeytin güvesi (Prays oleae Bern.)'nin popülasyon değișimi ve zarar oranı üzerinde ön çalışmalar. Zirai Mücadele Araştırma Yıllı̆̆ , No: 24-25, (1989-1990), Ankara, s. 82.

Broumas, T., 1987. Relationship between in festation and captures of adult of Prays oleae in pheromone traps. Annales de I'Institut Phytopatologique Benaki, 15(2): 163-172.

Çakıllar, M., 1959. Marmara Bölgesi'nde zeytin güvesinin biyolojisi üzerinde araştırmalar. T.C. Ziraat Vekâleti Zirai Mücadele ve Zirai Karantina Umum Müdürlüğü yayını, İstanbul Matbaası, İstanbul.

Çetin, H., Alaoğlu, Ö., 2005. Mut (Mersin) ilçesinde Zeytin güvesi (Prays oleae Bern.) (Lepidoptera: Hyponomeutidae)'nin popülasyon değişimi ve zararı üzerinde araştırmalar. Türkiye Entomoloji Dergisi, 29(2): 125-134

Güçlü, Ş., Hayat, R., Özbek, H., 1995. Artvin ve yöresinde zeytin (Olea europaea L.)'de bulunan fitofag ve predatör böcek türleri. Türkiye Entomoloji Dergisi, 19(3): 231-240.

Hegazi, E.M., Konstatopoulou, M.A., Herz, A., Mazomenos, B.E., Khafagi, W.E., Agamy, E.,
Zaitun, A., Abd El-Aziz, G.M., Showiel, S., AbdelRahman, S.M., 2009. Is mating disruption effective in controlling the olive month, Prays oleae. Crop Protection, 28: 181-189.

Kaplan, C., Büyük, M., Eren, S., 2004. GAP Bölgesi'nde zeytin ağaçlarında zarar yapan Zeytin güvesi [Prays oleae (Bern.)] (Lepidoptera: Hyponomeutidae)'nin popülasyon değișimi ve bulaşma oranı üzerinde çalışmalar. Türkiye 1. Bitki Koruma Kongresi Bildirileri, 8-10 Eylül, Samsun, s. 75.

Katsoyannos, P., 1992. Olive pests and their control in the Near East. Food and Agriculture Organization of the United Nation, Rome,1992.

Kaya, M., Yalçın, E., Soydanbay, M., 1985. Ege Bölgesi zeytinlerinde zarar yapan Zeytin güvesi (Prays oleae Bern.)'nin nesillere göre popülasyon değişimi, ekonomik savaşım eşiği ve savaş yöntemlerinin geliştirilmesi üzerinde araştırmalar. Doğa Türk Tarım ve Orman Dergisi, 11(1): 67-95.

Özkaya, M.T., Tunalığlu, R., Erken, Ş., Ulaş, M., Tan, M., Danac1, A., İnan, N., Tibet, Ü., 2010. Türkiye zeytinciliğin sorunları ve çözüm önerileri. Ziraat Mühendisliği VII. Teknik Kongresi, 11-15 Ocak, Ankara, s. 515-537.

Ramos, P., Campos, M., Ramos, J.M., 1998. Long-term study on the evaluation of yield and economic losses caused by Prays oleae Bern. in the olive crop of Granada (Southern Spain). Crop Protection, 17(8): 645-647.

Tunalığlu, R., 2015. Türkiye'de Zeytincilik ve Pazarlama Politikaları: 2000-2010. Tartm 2015 Zeytin ve Zeytinyağı Sempozyumu, 29 Mayıs, İzmir, s. 143.

Turanl1, T., Kaplan, C., Hepdurgun, B., 2011. İzmir ve Manisa illeri zeytinliklerinde zarar yapan Zeytin güvesi [Prays oleae (Bern.)] (Lepidoptera: Hyponomeutidae)'nin popülasyon değişimi ve zarar oranın belirlenmesi. Türkiye IV. Bitki Koruma Kongresi Bildirileri, 28-30 Haziran, Kahramanmaraş, s. 303.

Yayla, A., 1983. Antalya ili zeytin zararlıları ile doğal düşmanlarının tespiti üzerinde ön çalışmalar. Bitki Koruma Bülteni, 23(4): 188-207. 